\title{
Financial Crises and Key Economic Sectors of China and India: A Comparative Review of 1991-2010
}

\author{
Muhammad Umar Draz, ${ }^{1, *}$ Fayyaz Ahmad ${ }^{2}$ \\ ${ }^{1}$ Department of Management and Humanities, Universiti Teknologi PETRONAS, 32610 Seri Iskandar, Perak, Malaysia \\ ${ }^{2}$ School of Economics, Lanzhou University, 222 Tianshui South Road, 730000 Lanzhou, Gansu, China
}

\begin{abstract}
Economic growth of emerging Asian economies like China and India has been a topic of interest for researchers. However, most of the existing studies have focused on economic growth trends of China and India. The aim of this paper is to identify the core sectors of both economies and analyse the impact of the Asian financial crisis of 1997 and the global financial crisis of 2008 on the performance of those sectors. We also intend to explore the impact of the aforementioned financial crises on the overall economic growth of both nations. Our review consists of five years' average and critical analysis of the existing studies to identify the key sectors of economy and to analyse the impact of financial crises. The results indicate that industry and service sectors are the highest contributors in the GDP of China and India respectively. We also found heterogeneous impact of financial crises on the key sectors of both nations' economy.
\end{abstract}

\section{Introduction}

China and India comprise of more than one third of the world's population. At present, both of these nations are among the major exporting economies of the world. China is one of the fastest growing economies and its average annual growth rate was $9.1 \%$ during the last decade (Lane \& Schmukler, 2007). Within a short span of time, China has become a key Asian economy followed by India and other emerging economies in the region. From 1980 to 2007, China's share in the world economy increased from $1.7 \%$ to $5.9 \%$, while India's share in the global economy was 2.2\% in 2007 (Jarko \& Iikka, 2009). Although China was the third largest economy of the world in 2008 subsequent to USA and Japan respectively; at present, it has already surpassed Japan and has emerged as the second largest economy. During the global financial crisis of 2008, economic growth of China has slowed down and the Chinese government announced bailout to rebuild the infrastructure and to ensure sustainable economic growth (Yuan et al., 2010).

India is one of the leading competitors of China among the Asian emerging economies. During the last two decades, Indian economy has made a great progress in different sectors like information technology (IT), textile and a number of other sectors. Because of its more liberal foreign trade policies, India has recently become an attractive place for foreign investors. Before the global financial crisis of 2008, Indian economy was flourishing with a remarkable growth rate of around $9 \%$. Exports sector is a significant component of the growing Indian economy; average growth rate in this sector was $25.8 \%$ before 2008 and the share of exports sector in GDP was $14.2 \%$ during 2007-08. However, with the outbreak of financial crisis in 2008, just like advanced countries, Emerging Market Economies (EMEs) also suffered from downfall in economic activities and faced large scale unemployment. Indian economy was no exception to this catastrophe and its industrial production collapsed to $2.7 \%$. Furthermore, during the crisis of 2008, Indian exports growth rate was only $5.4 \%$ and the rising commodity prices resulted into inflation (Viswanathan, 2010).

Considering the growth and increasing share of India and China in the world economy, it will be insightful to study various economic sectors, their corresponding contribution in economy of both countries and the impact of financial crises on these economic sectors. The main objective of this study is to examine the contribution of different sectors, their performance during the last couple of decades and the impact of financial crises on the economic sectors of India and China. After reviewing previous studies, the next section provides details of the contribution of key economic sectors in GDP of both economies. Subsequently, impact of financial crises on GDP

\footnotetext{
* Corresponding author: umar.draz@utp.edu.my
} 
growth and the key economic sectors is determined. The final section presents findings and discussion for policy implications.

\section{Literature Review}

Since 1980, India and China have made great efforts to achieve economic growth and stability in different sectors of their economies. Back in 1980, per capita GDP of India was approximately equal to the World Bank's average for low income countries, while China was well behind India in terms of per capita GDP (Bosworth \& Collins, 2008). However, China had a tremendous record of GDP growth during the last decade but the rate of growth is expected to slow down during the on-going decade; on the other hand, as compared to China, India is estimated to face more uncertainty in achieving potential GDP growth rate during the same time span (Kuijs, 2012). In a comparative study of China and Pakistan, Draz (2011) concluded that Chinese economy faced more ups and downs due to external crises as compared to Pakistan. Internal issues of Pakistan had catastrophic effects on economy in comparison with external crisis.

Both China and India were affected by the global financial crisis of 2008 that brought in the most severe recession since the Great Depression of 1929. The responses to global financial crisis varied from country to country. A stimulus package of 787 billion dollars was passed by the USA Congress to rescue its financial institutions and to reassure people that their money is safe; however, China took different measures to strengthen its financial institutions by utilizing its huge amounts of reserves. It is a fact that despite rising unemployment and decline in exports, China took advantage of the opportunity created by the global financial crisis of 2008 and spent enormous funds on research and development in various institutions. At present, China is gaining access to the resources of Latin America, Africa, Middle East and elsewhere. China is also acquiring European and American companies; one of the most visible acquisitions is Hummer from General Motors (Payne, 2012).

China has over 500 million people in its rural labour workforce; during the financial crises of 2008, more than 49 million rural workers lost their jobs and were forced to return to their homes due to unemployment (Huang et al., 2011). Allen et al. (2005) gave credit of growing Chinese economy to its private sector, which is more efficient than public sector. Though Chinese economy is growing fast, its financial, legal and governing mechanism is somewhat underdeveloped, which is obviously a negative sign for sustainable growth. Chinese economy is exportoriented and foreign trade is very crucial for China. As described by Yuan et al. (2010), recent studies confirm that China's GDP growth decreased by $7.33 \%$ due to financial crisis of 2008 and $9.21 \%$ reduction was observed in energy consumption as well. Thus, China is facing difficulties in achieving sustainable economic growth.

Negative impact of financial crisis of 2008 can also be observed on Indian economy; its average economic growth rate decreased from $8.8 \%$ to $6.7 \%$ during 2008-2009. To encounter this shortfall, Indian government introduced various stimulus packages, e.g. tax rebates and increases in public expenditures; as a result, economic growth went up to $8.6 \%$ during the fiscal year 2010-2011. This tremendous pace made India the fastest growing economy after China (Bajpai, 2011). Indian exports were mostly service-oriented in the last decade and its progress in exporting services was incredible; however, this growth declined during the financial crisis of 2008 and India's real GDP growth also slowed down (Ghosh \& Chandrasekhar, 2009). Despite the reality that China and India had experienced a decline in economic activities during the financial crisis of 2008, as described by Gay (2008), both countries still ranked among the top ten economies of the world.

China and India are two strong pillars of the Asian economy; although both nations have different business cycle from the rest of the world, it has been observed that the financial crisis of 2008 brought Chinese and Indian business cycles closer to the Organization of Economic Cooperation and Development (OECD) economies (Jarko \& Iikka, 2009). The work of Aloui et al. (2011) depicts that both China and India are advancing towards economic openness and focusing more on enhancing their foreign trade. In this context, share of both nations can be easily observed through their trade to GDP ratio which is $71.3 \%$ and $44.9 \%$ respectively. The authors further stated that economic growth of China and India highly depends on exports of manufactured goods and services; moreover, their stock market is less dependent on the USA as compared to Russia and Brazil, which are other two main players among EMEs.

According to Lane \& Schmukler (2007), China and India are very important for the world economy due to their financial integration and play a crucial role in the Asian and international markets. The main impact of China's financial integration on the international system is due to its large foreign reserves that are very helpful against adverse financial shocks. Generally speaking, India and China are attracting more investment by allowing capital liberalization and an open market across borders; these enhanced capital inflows can help both nations to sustain 
their economic growth and cope with the global financial crisis. Furthermore, as stated by De (2009), China and India can increase their trading activities in Asia as their magnitude of trade potential is the maximum in Asia and pacific region; both countries can achieve a higher level of growth by adopting the policy of trade facilitation and liberalization.

Examining the link between financial crisis and stock market volatility of Asian markets, Singhania \& Anchalia (2013) found that sub-prime crisis of 2008 was positively linked and the Eurozone debt crisis was negatively associated with the Chinese, Indian and Japanese markets; furthermore, volatility, clustering, asymmetries and leverage effects are observed in these stock markets.

Investigating the impact of financial crises on economic activities in Southeast Asia, Cevik et al. (2016) found that the economic turmoil caused a significant slowdown in economic growth and increased uncertainty in the financial markets. Investigating stock and currency markets of China, Eurozone, India, Japan and the USA, Dua \& Tuteja (2016) confirmed a negative impact of turmoil; the diversification benefits were also adversely affected during the global and Eurozone crisis. Using a novel approach to confirm the spill over effects in integrated international stock markets, Marfatia (2017) concluded that, contrary to the general view, the spill over risk was limited to specific economies; in fact, the evidence for China, India and Malaysia is not significant.

Assessing the output losses and the corresponding policies in advanced, developing and lower income countries, Tola \& Waelti (2018) suggested that the crises' impact varies for different economies and not all policy measures are effective to cover the output losses from turmoil. The global financial crisis of 2008 caused a more severe recession in the advanced economies as compared to the emerging ones. China and other resource-rich economies prevented the abrupt decline in GDP but the situation turned more challenging lately. The findings for individual BRICS economies indicated that China has significant influence on other economies; the spill over effects from China are more significant for natural resource rich economies (Belke et al., 2018).

Among the comparative studies on economic growth of China and India, most of the researchers have addressed the economic growth trends of both nations. The aim of our paper is to identify the impact of financial crises on the performance of key economic sectors of both. We used the annual data ranging from 1991 to 2010. The data source for all variables is the World Bank Economic Indicators. Taking our aim for this study into account, both Asian financial crisis of 1997 and the global crisis of 2008 are covered in our sample data. Additionally, using this data range, the impact of crisis can be compared with pre and post crisis scenarios. Therefore, we suggest that our data range is a rational choice for the comparison of results. Our work adds to the present literature by addressing the following research questions:

1. What were the key sectors of Chinese and Indian economy during 1991-2010?

2. Did financial crises affect the key sectors of both nations' economy during 1991-2010?

3. Which country's economy was affected more by the financial crises during 1991-2010?

\section{Key Sectors of Economy}

According to the World Bank, economy of a country can be divided into three sectors, i.e. agriculture, industry and service sector. The following sections provide the details of these key sectors of the Chinese and Indian economies:

\subsection{Agriculture}

Green revolution was beneficial for both China and India. As stated by Bosworth \& Collins (2008), China's growth in agriculture sector was aided by fundamental reforms beginning with restoration of family farms in the late 1970s and the shift of a large number of workers into the rural enterprises; another reason of growth was delegation of power to the local government in the late 1980s and 1990s. Due to steady introduction of market incentives, domestic and foreign owned private enterprises emerged as drivers of growing economy and China seemed to become committed to the development of "socialist market economy". The share of China's agriculture sector in GDP was lower than that of India's since 1990. In 1990, the difference was small, but in coming years, a persistent decline can be observed in China's agriculture sector in terms of its share in country's GDP.

Table 1: Contribution of agriculture sector in GDP (in \%) 


\begin{tabular}{|c|c|c|c|c|c|}
\hline Phase & Year & China & India & Average (China) & Average (India) \\
\hline \multirow{5}{*}{1} & 1991 & 24.53 & 29.39 & \multirow{5}{*}{21.16} & \multirow{5}{*}{28.26} \\
\hline & 1992 & 21.79 & 28.74 & & \\
\hline & 1993 & 19.71 & 28.68 & & \\
\hline & 1994 & 19.86 & 28.27 & & \\
\hline & 1995 & 19.96 & 26.26 & & \\
\hline \multirow{5}{*}{2} & 1996 & 19.69 & 27.13 & \multirow{5}{*}{17.41} & \multirow{5}{*}{25.31} \\
\hline & 1997 & 18.29 & 25.89 & & \\
\hline & 1998 & 17.56 & 25.79 & & \\
\hline & 1999 & 16.47 & 24.65 & & \\
\hline & 2000 & 15.06 & 23.12 & & \\
\hline \multirow{5}{*}{3} & 2001 & 14.39 & 23.00 & \multirow{5}{*}{13.28} & \multirow{5}{*}{20.47} \\
\hline & 2002 & 13.74 & 20.75 & & \\
\hline & 2003 & 12.80 & 20.77 & & \\
\hline & 2004 & 13.39 & 19.03 & & \\
\hline & 2005 & 12.12 & 18.81 & & \\
\hline \multirow{5}{*}{4} & 2006 & 11.11 & 18.29 & \multirow{5}{*}{10.60} & \multirow{5}{*}{18.01} \\
\hline & 2007 & 10.77 & 18.26 & & \\
\hline & 2008 & 10.73 & 17.78 & & \\
\hline & 2009 & 10.33 & 17.74 & & \\
\hline & 2010 & 10.06 & 17.98 & & \\
\hline \multicolumn{4}{|c|}{$1991-2010$} & 15.61 & 23.01 \\
\hline
\end{tabular}

Source: The World Bank

We have divided the contribution of agriculture sector in China and India's GDP into four phases of five years each. India's agriculture sector, as shown in table 1, contributed around 29\% of the GDP in 1991, i.e. comparatively higher than China. However, a subsequent downward trend can be observed for two decades. In the first year of second phase (i.e. 1996), China seems to have a revival, but no upward movement from India's agriculture sector was observed. During the next four years, both countries faced a decline in the share of its agriculture sector; subsequently, this decline was steady until 2010, but less sharp for both countries. We can easily observe in table that the overall contribution of China's agriculture sector in its GDP was lower than that of India's.

\subsection{Industry}

The industrial sector, which includes manufacturing, construction and some other divisions, has surprisingly different contribution in the GDP of both nations. This sector provides nearly half of the GDP in case of China, whereas in case of India, industry sector's average contribution has remained below 30\% during 1991-2010. In this period, China achieved spectacular growth in industry sector right from the start of 1990s, while India also tried to sustain its performance in industry sector. During the first phase, growth of China's industry sector was tremendous and India's industry sector was also on progressive track. As shown in table 2, China's industry share in GDP was steady during 1996-97 with a rising trend as compared to phase 1, but its industry's annual GDP share moved downwards in the next three years. Meanwhile India was also on the way with a minor declining ratio during 1996-1999 as compared to previous five years period.

An overall increasing trend for both countries was observed in the last phase. In year 2006, China achieved its maximum contribution from industrial sector during the last two decades and India's industrial sector achieved this milestone in 2007. Overall contribution of industry in GDP of China and India was encouraging with a few slowdowns, which is observable for both countries in table 2. Percentages of industry sector's contribution in GDP support that industrial sector is flourishing and consistently contributing in GDP growth of both nations. A few downfalls in industry's share are the indication of economic and financial shocks around the globe which are common for any integrated economy. 
Table 2: Contribution of industry sector in GDP (in \%)

\begin{tabular}{|c|c|c|c|c|c|}
\hline Phase & Year & China & India & $\begin{array}{l}\text { Average } \\
\text { (China) }\end{array}$ & Average (India) \\
\hline \multirow{5}{*}{1} & 1991 & 41.79 & 25.40 & \multirow{5}{*}{45.11} & \multirow{5}{*}{26.10} \\
\hline & 1992 & 43.45 & 25.77 & & \\
\hline & 1993 & 46.57 & 25.50 & & \\
\hline & 1994 & 46.57 & 26.41 & & \\
\hline & 1995 & 47.18 & 27.40 & & \\
\hline \multirow{5}{*}{2} & 1996 & 47.54 & 26.60 & \multirow{5}{*}{46.59} & \multirow{5}{*}{26.05} \\
\hline & 1997 & 47.54 & 26.41 & & \\
\hline & 1998 & 46.21 & 25.74 & & \\
\hline & 1999 & 45.76 & 25.37 & & \\
\hline & 2000 & 45.92 & 26.11 & & \\
\hline \multirow{5}{*}{3} & 2001 & 45.15 & 25.17 & \multirow{5}{*}{45.90} & \multirow{5}{*}{26.70} \\
\hline & 2002 & 44.79 & 26.23 & & \\
\hline & 2003 & 45.97 & 26.05 & & \\
\hline & 2004 & 46.23 & 27.93 & & \\
\hline & 2005 & 47.37 & 28.13 & & \\
\hline \multirow{5}{*}{4} & 2006 & 47.95 & 28.84 & \multirow{5}{*}{47.11} & \multirow{5}{*}{28.30} \\
\hline & 2007 & 47.34 & 29.03 & & \\
\hline & 2008 & 47.45 & 28.29 & & \\
\hline & 2009 & 46.24 & 27.76 & & \\
\hline & 2010 & 46.57 & 27.57 & & \\
\hline \multicolumn{4}{|c|}{$1991-2010$} & 46.18 & 26.79 \\
\hline
\end{tabular}

Source: The World Bank

\subsection{Services}

Services sector has become the fastest growing sector of the global economy since last two decades. As Banga (2005) mentioned, this sector is providing more than $60 \%$ of the global output and the same percentage of employment in many countries of the world. Due to the huge contribution of this sector in economy, a significant shift of foreign direct investment from manufacturing sector to services sector can be observed worldwide. At present, following the global trend, servicing sector is flourishing in India as well. It can be observed from data in table 3 that the share of services sector is more than industrial and agriculture sector in Indian economy. Since last decade, this is the most significant sector contributing 54\% towards GDP of India. The expansion of this sector has also been strong in China. This sector is the second largest contributor in GDP of China next to its industrial sector.

In phase one starting from 1991, India's services sector contributed more towards GDP as compared to China. This phase worked fairly for China as well, except in the last year, i.e. 1995. During the second phase, both countries were steady towards achieving the goal of increasing the share of services sector in their GDP. It can be observed from table 3 that both countries were successful to achieve their goal by the end of second phase. During phase one and two, though China was behind India in terms of share of services sector in GDP, but its progress was consistent.

Table 3: Contribution of services sector in GDP (in \%)

\begin{tabular}{|c|c|c|c|c|c|}
\hline Phase & Year & China & India & $\begin{array}{c}\text { Average } \\
\text { (China) }\end{array}$ & Average (India) \\
\hline \multirow{4}{*}{1} & 1991 & 33.69 & 45.21 & & \\
\cline { 2 - 4 } & 1992 & 34.76 & 45.49 & \multirow{2}{*}{33.72} & 45.64 \\
\cline { 2 - 4 } & 1993 & 33.72 & 45.83 & & \\
\cline { 2 - 4 } & 1994 & 33.57 & 45.32 & & \multirow{2}{*}{48.64} \\
\cline { 2 - 4 } & 1995 & 32.86 & 46.34 & & \\
\hline \multirow{3}{*}{2} & 1996 & 32.77 & 46.27 & & \\
\cline { 2 - 4 } & 1997 & 34.17 & 47.70 & & \\
\cline { 2 - 4 } & 1998 & 36.23 & 48.47 & & \\
\cline { 2 - 4 } & 1999 & 37.77 & 49.98 & & \\
\hline
\end{tabular}




\begin{tabular}{|c|c|c|c|c|c|}
\hline & 2000 & 39.02 & 50.76 & & \\
\hline \multirow{5}{*}{3} & 2001 & 40.46 & 51.83 & \multirow{5}{*}{40.81} & \multirow{5}{*}{52.83} \\
\hline & 2002 & 41.47 & 53.02 & & \\
\hline & 2003 & 41.23 & 53.18 & & \\
\hline & 2004 & 40.38 & 53.05 & & \\
\hline & 2005 & 40.51 & 53.06 & & \\
\hline \multirow{5}{*}{4} & 2006 & 40.94 & 52.87 & \multirow{5}{*}{42.29} & \multirow{5}{*}{53.69} \\
\hline & 2007 & 41.89 & 52.71 & & \\
\hline & 2008 & 41.82 & 53.93 & & \\
\hline & 2009 & 43.43 & 54.50 & & \\
\hline & 2010 & 43.37 & 54.45 & & \\
\hline \multicolumn{4}{|c|}{ 1991-2010 } & 38.20 & 50.20 \\
\hline
\end{tabular}

A prominent increase in the average of both countries can be noticed at the end of second phase. At the start of phase three, services sector of both China and India contributed more towards GDP; both countries performed well, especially during the first three years of this phase. India's service sector contributed more than China's service sector in these three years. During the last two years of phase three, both countries' services sectors faced a slight downfall. During the last phase, India's service sector was less steady as compared to previous decade. In first two years of phase four, share of India's service sector in GDP declined, but India sustained its previous trend in the coming years of this phase.

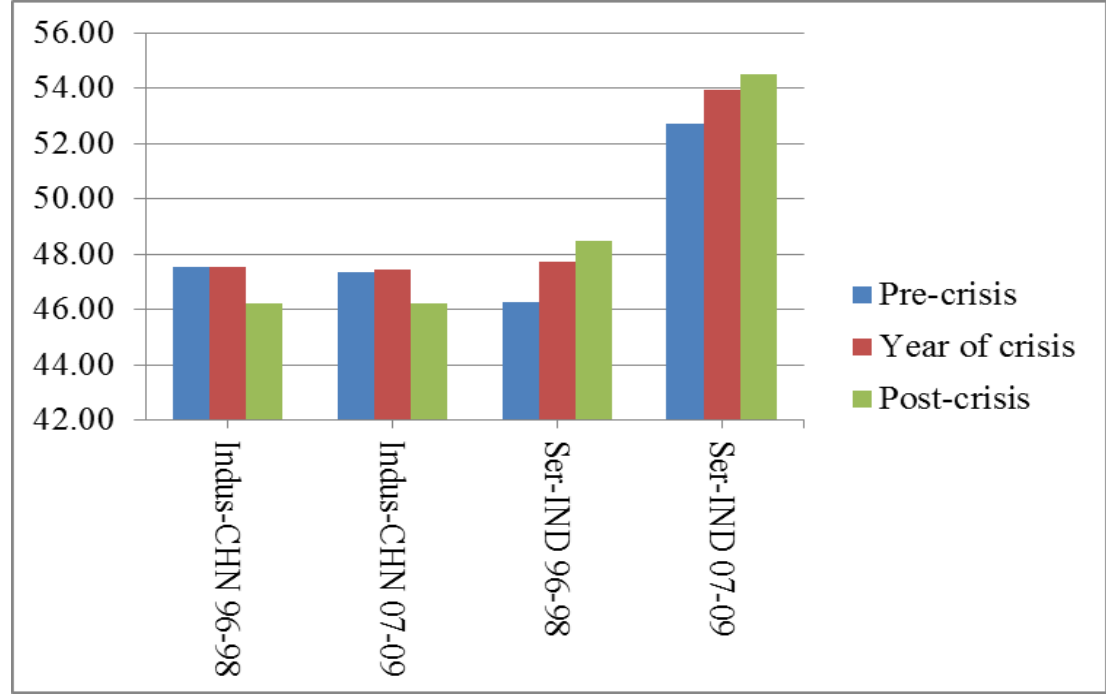

Figure 1: Average Contribution of the Key Sectors in GDP

On the other hand, China's service sector made a tremendous effort to increase its contribution in GDP during phase four. At the end of 2010, the share of service sector for China was $43.37 \%$, which was significantly higher than the previous decade. Percentage changes in table 3 indicate that service sector is flourishing in both countries. Share of China's service sector is gradually increasing since last decade. Though contribution of this sector is the highest in case of India, the per annum growth is somehow lower than China's service sector. Perhaps it's an indication of saturation for India.

Figure 1 indicates the average share of every sector of economy in GDP of both countries during the last two decades. Agriculture sector is the smallest contributor towards GDP of China with an average share of $15.61 \%$ in GDP. On the other hand, Indian agriculture sector is also at the bottom in terms of its share in GDP, but the percentage of contribution, i.e. 23.01\%, is higher than China's agriculture sector. The second largest contributor in China's GDP was its services sector and China has made progress in this sector since the last decade. The average contribution of services sector in Chinese economy is $38.20 \%$ for the last two decades. In case of India, the 
industrial sector is the second largest contributor towards GDP; this sector's average contribution during the last two decades was $26.79 \%$. The strongest pillar of China's economy during 1991-2010 was its industrial sector; the average contribution of industrial sector in GDP of China was 46.18\% for 1991-2000. The most prominent sector of the Indian economy was its services sector, which contributed $50.20 \%$ on average to the GDP during the last two decades.

\section{Financial Crises and the Key Sectors of Economy}

The global financial crisis of 2008 had devastating effects on the whole world including developed countries. The slowdown of growth in leading countries of the world affected EMEs as well. India and China also faced the impact of this crisis. For instance, as described by Siddiqui (2009), the growth of industrial output of India declined sharply to $-2.3 \%$ in March 2009 and Index of Industrial Production (IIP) fell by -3.3\%; the author further stated that not only developing countries like China and India, but economies like the USA were also severely affected. During 2009, the budget deficit of the USA was $12 \%$ of its GDP and the interest rates were reduced to almost zero percent in order to stimulate the economy.

China and India both are populated countries and have billions of people to feed; therefore, agriculture sector is one of the major sectors of both countries. During 1997, as shown in figure 2, both China and India faced a decrease in their share of value added GDP from agriculture sector. The share of China was declined by $1.4 \%$ as compared to 1996, while the share of Indian agriculture sector was declined by $1.24 \%$ as compared to 1996 . During 1991-2010, the agriculture sector of both countries had a declining trend in terms of contribution towards GDP and this trend remained steady. The global financial crisis of 2008 did not affect the agriculture sector of both nations severely, and like previous years, the same declining trend of this sector continued.

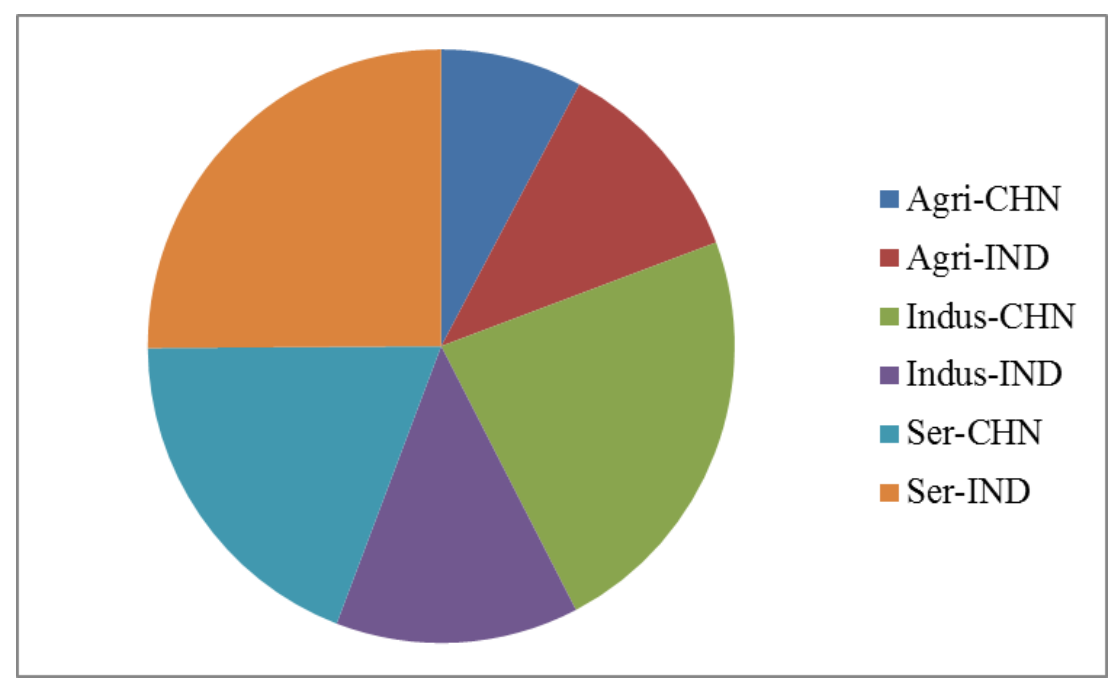

Figure 2: Impact of financial crises on the key sectors of economy

Industrial sector is the largest contributor of China's GDP and it is the second largest sector for India. During Asian financial crisis of 1997, both countries faced a slowdown in terms of contribution of industry sector towards GDP, but the impact of this crisis on India was sharp. In 1997, the share of Indian industrial sector dropped down by $0.19 \%$ as compared to 1996 . Although China's industry sector sustained during 1997, but its share in GDP dropped down by $1.33 \%$ during 1998 . Both countries' industry sector took a significant amount of time to restore their pre-crisis position. Industry sector of China was more stable during the global financial crisis of 2008 as compared to India's industry sector. In 2008, the growth of Indian industry sector declined from $29.03 \%$ to $28.29 \%$, but China's industry sector growth increased by $0.11 \%$ as compared to 2007. In the next year (i.e. 2009), the share of Chinese industry sector decreased but recovered in 2010; on the contrary, the industry sector of India had a declining trend until 2010. Therefore, it is clear that the global financial crisis of 2008 was more devastating for the Indian industrial sector as compared to China's. 
The biggest sector in Indian economy is service sector and it is the second largest contributor in GDP of China. Both countries' service sector had good growth rates during the Asian financial crisis of 1997 and the trend for both China and India was sustained in the year of crisis. Although the percentage share of this sector is significant for India than China, but the difference between growth rates is distinct for both countries. India experienced the same growth trend, i.e. increasing trend, during the global financial crisis of 2008 as it was during the Asian financial crisis.

In this section we compared the performance of industry sector of China and servicing sector of India before and after one year of Asian financial crisis and global financial crisis of 2008. As shown in figure 2, the growth of Chinese industrial sector in 1996 was $47.54 \%$ and it sustained during the year of crisis; however, it dropped down during 1998. During global financial crisis of 2008, the growth percentage of China's industry sector was significant in the year of crisis, but a downward movement can be observed in 2009. On the other hand, the trend is opposite in case of India. In 1998, the growth percentage of India's service sector was higher than the crisis and pre-crisis years. The same pattern can be observed in case of India during the global financial crisis of 2008. Overall, an interesting pattern can be noticed for two sectors of both countries in terms of growth percentage, i.e. it is a descending trend for China's key economic sector and an ascending trend for India's key economic sector.

\section{Financial Crises and Economic Growth of China and India}

The Asian financial crisis of 1997 left its devastating effects. The countries that were once known as 'the Asian miracle' faced severe economic conditions during this crisis. During July 1997, Thai baht broke its peg with the USD and, as mentioned by Chakrabarti \& Roll (2002), Thailand lost $65 \%$ of its stock market value in terms of USD in the next six months. Decrease in stock market value for Hong Kong was 33\%, Indonesia lost 71\%, Malaysia 57\%, the Philippines 58\%, Singapore $24 \%$ and South Korea lost $44 \%$ of its stock market value. The next shock to the world economy was the global financial crisis of 2008. This crisis left its impact on various countries worldwide; however, the effects of this crisis varied from country to country.

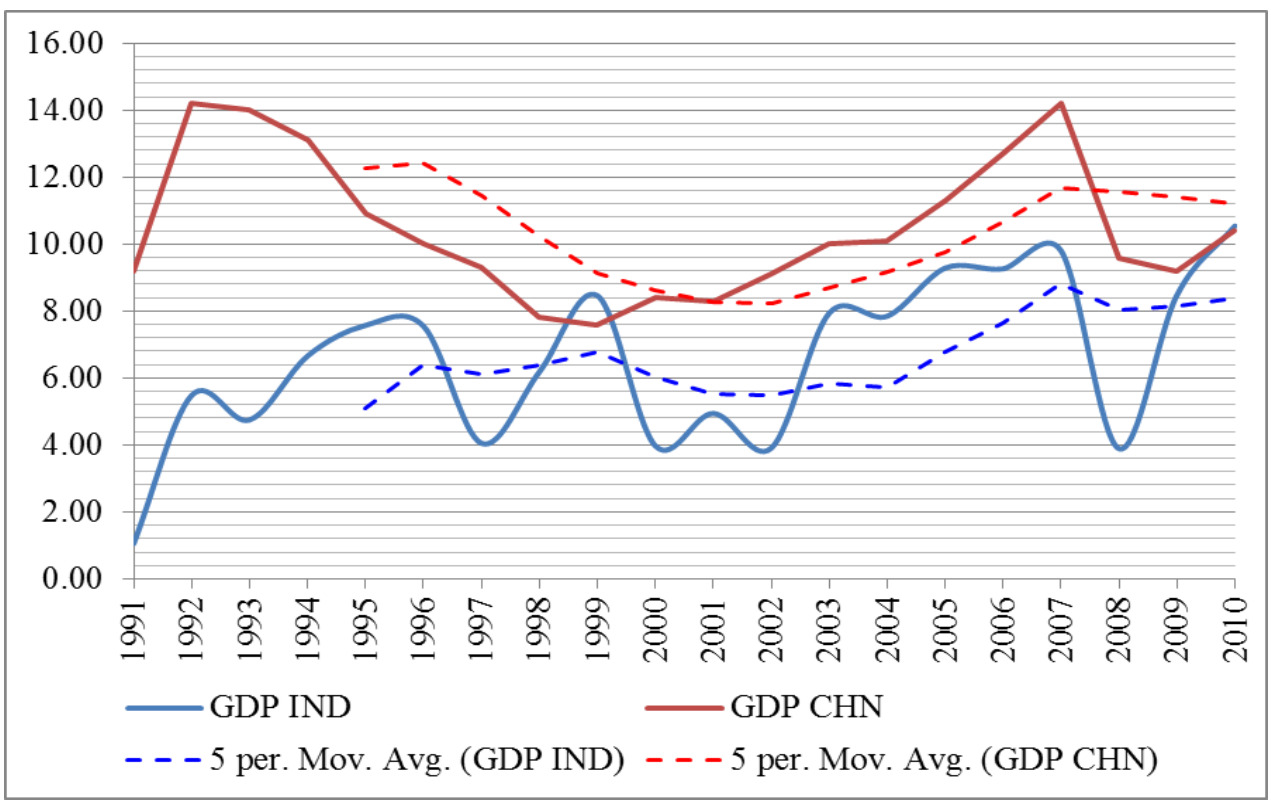

Figure 3: GDP Growth and its 5 Years Moving Average

China and India are globally integrated and own a respectable position among the EMEs. The GDP growth rate of both countries has been impressive during the last two decades; however, China's GDP growth has been better as compared to India's. As shown in figure 3, the GDP of both countries fluctuated during 1991-2010, but the Indian GDP graph shows more fluctuations. During the Asian financial crisis of 1997, both China and India faced a 
declining trend. It can be observed in figure 3 that China went through a trough while India's GDP was fluctuating. The crisis was more lethal for India as compared to China during 1997. Though the GDP growth rate was less than the pre-crisis period, but the overall trend was encouraging for China; however, India faced a decreasing trend in GDP until 2002. During the global financial crisis of 2008, the GDP of both countries decreased sharply but percentage of decline was comparatively more significant for India. Both countries recovered earlier as compared to the Asian financial crisis. In year 2010, the GDP growth percentage of India became better than China.

As five years moving shows that both China and India experienced declining trend during crisis, but more fluctuations can be observed in case of India. Though China went through a trough, its overall GDP growth was smoother and steadier as compared to India. During the Asian financial crisis, five years moving average of India showed increasing trend, but at the time of global financial crisis, China's moving average was better. Speaking further the GDP growth of India was less steady during 1991-2010 as compared to China's GDP growth; the changes were unexpected as it can be learnt from the moving average of India.

\section{Concluding Remarks}

This comparative review shows that manufacturing and servicing sectors are the highest contributors in GDP of China and India respectively, and contribute more than fifty percent to the GDP of their respective nation. Though both countries experienced impressive growth during 1991-2010, but financial crises also left their impact on both countries. There are some commonalities, but India has been more significantly affected by financial crises than China. GDP of China followed normal trend and no sharp changes occurred during and after the crises period, while India experienced sharp declines and failed to sustain its recovery trend. Likewise, the impact of both crises for India indicated that GDP has fallen sharply than China and relatively for longer tenure.

Comparison of the largest sectors before and after a year of crisis revealed interesting facts; impact of crisis is heterogeneous for both countries, i.e. GDP growth of China moved in descending order while Indian economy demonstrated ascending pattern, and indicated to be unaffected. But in the long run, Indian economy took more time to recover showing inconsistency and sustainability issues. Analysis of agriculture sector reveals that the share is sharply declining with every coming year for both China and India. However, share of India's agriculture sector in GDP is comparatively higher. On one hand, this is the sign of economic transformation, but on the other hand, this situation is alarming for both nations as it could lead to severe food shortage in the future.

Finally, in terms of contribution in GDP, the policy makers should emphasize on bottlenecks especially in agriculture sector to improve and sustain its production. Plenty of room is available for China to progress in its service sector; effective strategies are required to achieve significant and progressive performance of this sector. Long run sustainability is the main issue that Indian authorities need to address; effective policies can also increase efficiency of its industrial sector and lift up the share of agriculture sector as well.

\section{References}

Allen, F., Qian, J., \& Qian, M. (2005). Law, Finance and Economic Growth in China. Journal of Financial Economics, 77(1), 57-116.

Aloui, R., Aïssa, M. S., \& Nguyen, D. K. (2011). Global Financial Crisis, Extreme Interdependences, and Contagion Effects: The Role of Economic Structure? Journal of Banking \& Finance, 35(1), 130-141.

Bajpai, N. (2011). Global Financial Crisis, its Impact on India and the Policy Response. Mumbai: Columbia Global Centres | South Asia, Columbia University.

Banga, R. (2005). Capital Issues in India's Service-Lend Growth. New Delhi: Indian council for Research on Internationa Economic Relations.

Belke, A., Dreger, C., \& Dubova, I. (2018). On the Exposure of the BRIC Countries to Global Economic Shocks. The World Economy, 1-21.

Bosworth, B., \& Collins, S. M. (2008). Accounting for Growth: Comparing China and India. Journal of Economic Perspectives, 22(1), 45-66. 
Cevik, E. I., Dibooglu, S., \& Kenc, T. (2016). Financial Stress and Economic Activity in Some Emerging Asian Economies. Research in International Business and Finance, 36, 127-139.

Chakrabarti, R., \& Roll, R. (2002). East Asia and Europe during the 1997 Asian Collapse: A Clinical Study of a Financial Crisis. Journal of Financial Markets, 5(1), 1-30.

De, P. (2009). Global Economic and Financial Crisis: India's Trade Potential and Future Prospects. New Delhi: The Asia-Pacific Research and Training Network on Trade.

Draz, M. U. (2011). Impact of Financial Crises on Pakistan and China: A Comparative Study of Six Decades. Journal of Global Business and Economics, 3(1), 174-186.

Dua, P., \& Tuteja, D. (2016). Financial Crises and Dynamic Linkages Across International Stock and Currency Markets. Economic Modelling, 59, 249-261.

Gay, R. D. (2008). Effect of Macroeconomic Variables on Stock Market Returns for Four Emerging Economies: Brazil, Russia, India and China. International Business \& Economics Research Journal, 3(7), 1-8.

Ghosh, J., \& Chandrasekhar, C. P. (2009). The Costs of 'Coupling': the Global Crisis and the Indian Economy. Cambridge Journal of Economics, 33(4), 725-739.

Huang, J., Zhi, H. Y., Huang, Z. R., Rozelle, S., \& Giles, J. (2011). The Impact of the Global Financial Crisis on Offfarm Employment and Earnings in Rural China. World Development, 39(5), 797-807.

Jarko, F., \& Iikka, K. (2009). The Impact of the Global Financial Crisis on Business Cycles in Asian Emerging Economies. Munich: IFO Institute - Leibniz Institute for Economic Research.

Kuijs, L. (2012). Economic Growth Patterns and Strategies in China and India: Past and Future. Hong Kong: Fung Global Institute.

Lane, P. R., \& Schmukler, S. L. (2007). The International Financial Integration of China and India. Washington, DC: World Bank.

Marfatia, H. A. (2017). A Fresh Look at Integration of Risks in the International Stock Markets: A Wavelet Approach. Review of Financial Economics, 34, 33-49.

Payne, R. J. (2012). Global Issues. London, England: Pearson.

Siddiqui, K. (2009). Financial Crisis and Its Impact on the Economies of China and India. Research in Applied Economics, 1(1), 1-28.

Singhania, M., \& Anchalia, J. (2013). Volatility in Asian stock markets and global financial crisis. Journal of Advances in Management Research, 10(3), 333-351.

Tola, A., \& Waelti, S. (2018). Financial Crises, Output Losses, and the Role of Structural Reforms. Economic Inquiry, 56(2), 761-798

Viswanathan, K. G. (2010). The Global Financial Crisis and its Impact on India. Journal of International Business and Law, 9(1), 41-62.

Yuan, C., Liu, S., \& Xie, N. (2010). The Impact on Chinese Economic Growth and Energy Consumption of the Global Financial Crisis: An Input-Output Analysis. Energy, 35(4), 1805-1812. 